\title{
Broad-Scale Assessment of Rangeland Health, Grand Staircase-Escalante National Monument, USA
}

\author{
Mark E. Miller \\ Author is Research Ecologist, US Geological Survey, Southwest Biological Science Center, Kanab, UT 84741, USA.
}

\begin{abstract}
Over a 3-yr period, the qualitative assessment protocol "Interpreting Indicators of Rangeland Health" was used to evaluate the status of three ecosystem attributes (soil/site stability, hydrologic function, and biotic integrity) at over 500 locations in and adjacent to Grand Staircase-Escalante National Monument (Utah). Objectives were to provide data and interpretations to support the development of site-specific management strategies and to investigate broad-scale patterns in the status of different rangeland ecological sites. Quantitative data on ground cover, plant community composition, and soil stability were collected to aid the evaluation of qualitative attributes and improve consistency of the assessment process. Ecological sites with potential vegetation dominated by varieties of big sagebrush (Artemisia tridentata Nuttall) had the highest frequencies $(46.7 \%-75.0 \%$ ) of assessments with low ratings (moderate or greater departure from expected reference conditions) for all three ecosystem attributes. In contrast, sites with potential vegetation characterized by Utah juniper ( Juniperus osteosperma [Torrey] Little) and/ or Colorado pinyon (Pinus edulis Engelmann) had low frequencies $(0.0 \%-7.8 \%)$ of assessments with low ratings for all attributes. Several interacting factors likely contributed to the development of patterns among ecological sites, including 1) potential primary production and thus long-term exposure to production-oriented land uses such as livestock grazing; 2) the presence of unpalatable woody plants capable of increasing and becoming persistent site dominants due to selective herbivory, absence of fire, or succession; 3) soil texture through effects on hydrologic responses to livestock grazing, trampling, and other disturbances; and 4) past management that resulted in high livestock use of ecological sites with sensitive fine-loamy soils following treatments designed to increase forage availability. This case study illustrates an extensive application of an assessment technique that is receiving increasing use worldwide, and results contribute to an understanding of factors contributing to patterns and processes of rangeland degradation.
\end{abstract}

\section{Resumen}

Durante un período de tres años, se siguió el protocolo de interpretación de Indicadores de Salud de Pastizales, para evaluar el estado de tres atributos del ecosistema (Suelo /Estabilidad del Sitio, función hidrológica e integridad biótica) en mas de 500 áreas del Grand Staircase-Escalante National Monument (en Utah USA) y en áreas adyacentes. Con los objetivos de proporcionar datos e interpretaciones que apoyen el desarrollo de estrategias de manejo a sitios específicos, y para investigar los patrones a gran escala del estado de diferentes sitios ecológicos de pastizal. Se recolectaron datos cuantitativos sobre cobertura de suelo, composición vegetal de la comunidad, y estabilidad del suelo para ayudar a la evaluación de los atributos cualitativos y para mejorar la consistencia en el proceso de evaluación. Sitios ecológicos con la vegetación potencial dominada por el arbusto (Artemisia tridente Nuttall) tuvieron las mayores frecuencias con los índices de evaluación mas bajos $(46.7 \%-75 \%)$ con una diferencia moderada a grande en relación a la esperada con las áreas de referencia, para los tres atributos del ecosistema. En contraste, sitios con vegetación potencial caracterizados por el táscate (Juniperus osteosperma [Torrey] Little) y/o el Piñón colorado (Pinus edulis Engelmann) presentaron bajas frecuencias $(0.0 \%-7.8 \%)$ de evaluación con bajos índices para todos los atributos del ecosistema. La interacción de algunos factores probablemente contribuyó al desarrollo de patrones entre los sitios ecológicos, incluyendo 1) producción potencial primaria y por lo tanto largo tiempo que estas áreas estuvieron expuestas a la producción orientada del ganado en pastoreo; 2) la presencia de plantas leñosa de baja palatabilidad capaces de incrementar su población, llegando a ser dominantes y permanentes del sitio, debido al pastoreo selectivo, ausencia de fuego, o sucesión; 3) las textura del suelo y su efecto sobre respuesta hidrológica al pastoreo, pisoteo y otros disturbios; y 4) Historial de manejo, que da como resultado un alto grado de uso por el ganado en sitios ecológicos con suelos susceptibles de textura fina, seguidos por tratamientos diseñados para incrementar la disponibilidad de forraje. Este estudio ilustra una extensiva aplicación de una técnica de evaluación que está siendo utilizada más y más en todo el mundo y cuyos resultados contribuyen a un mejor entendimiento de los factores y patrones que causan la degradación de las áreas de pastizal.

Key Words: Artemisia tridentata Nuttall, big sagebrush, ecological sites, ecosystem assessment, rangeland condition, soil properties

Field work for this research was funded by the Bureau of Land Management. Data analyses and manuscript preparation were funded by the US Geological Survey (Southwest Biological Science Center and Earth Surface Dynamics Program) and supported by the Bureau of Land Management.

The use of trade, product, or firm names in this publication is for descriptive purposes only and does not imply endorsement by the US Government.

At the time this research was initiated, Miller was ecologist, Bureau of Land Management, Grand Staircase-Escalante National Monument, Kanab, UT 84741, USA.

Correspondence: Mark E. Miller, US Geological Survey, Southwest Biological Science Center, c/o Grand Staircase-Escalante National Monument, Kanab, UT 84741, USA. Email: mark_miller@usgs.gov

Manuscript received 27 September 2007; manuscript accepted 24 February 2008. 


\section{INTRODUCTION}

Over the past $15 \mathrm{yr}$, there has been a focused effort to develop new methods for assessing the status of rangeland ecosystems. This effort has been driven by increased recognition that 1) the dynamics of such ecosystems often are much more complex than previously assumed and 2) sustainable management requires consideration of a broader suite of ecosystem attributes than production of key forage species and similarity of the existing plant community to a single idealized climax community (see reviews by Pyke et al. 2002; Pyke and Herrick 2003; and Briske et al. 2005 for historical perspectives). In the United States, much of this effort directly followed recommendations made by expert panels convened by the National Research Council (NRC; NRC 1994) and the Society for Range Management Task Group on Unity in Concepts and Terminology Committee (SRM Task Group; SRM Task Group 1995). The NRC panel recommended that rangeland assessments should focus on indicators of soil stability, watershed function, nutrient cycling, energy flow, and recovery mechanisms (NRC 1994). The SRM Task Group observed that because the sustainable management of rangeland ecosystems depends primarily on soil conservation, assessments should evaluate rangeland plant communities in terms of their ability to protect a site against accelerated soil erosion (SRM Task Group 1995). Both panels recommended that assessments should be conducted and interpreted on the basis of a common system for classifying land units on the basis of soil, landscape setting, and climate analogous to the ecological site concept of the US Department of Agriculture Natural Resources Conservation Service (NRCS; NRCS 2003).

Both in the United States and in Australia, there has been rapid growth in research focusing on conceptual and applied aspects of rangeland assessment and monitoring, with a strong emphasis on indicators of ecosystem or landscape capacity to capture and retain soil and water resources. The majority of this work has focused on field-based indicators (Whitford et al. 1998; de Soyza et al. 2000a; Pyke et al. 2002; Rosentreter and Eldridge 2002; Tongway and Hindley 2004; Herrick et al. 2005; Pellant et al. 2005), but the need for approaches that can be applied affordably and effectively across expansive landscapes also has led to efforts focused on the development of indicators that can be reliably detected with remotely sensed imagery (de Soyza et al. 2000b; Ludwig et al. 2002, 2007). Rather than being a stand-alone activity, assessment increasingly is recognized as a key component of an integrated framework designed to support science-based management of rangeland ecosystems (Herrick et al. 2006).

To date, the most widely adopted assessment approach in the United States has been the technique "Interpreting Indicators of Rangeland Health" (IIRH; Pellant et al. 2000, 2005; Pyke et al. 2002). In this technique, an interdisciplinary team of resource specialists evaluates three ecosystem attributes (soil/site stability, hydrologic function, and biotic integrity) on the basis of a suite of qualitative indicators. IIRH is widely applied by NRCS, the Bureau of Land Management (BLM), and the National Park Service (NPS), and protocols have been translated into Spanish, Chinese, and Mongolian (J. Herrick, personal communication, August 2007).
Despite its widespread adoption and increasing use worldwide, there are no published examples of how the IIRH technique has been applied to evaluate the status of rangeland ecosystems across broad spatial extents characteristic of public lands in the western United States. The purpose of this paper is to describe one such project as a case study in which the technique was applied at over 500 locations in and adjacent to Grand Staircase-Escalante National Monument, Utah (hereafter, the Monument), over a 3-yr period. Objectives of this assessment project were 1) to provide data and interpretations to support the development of site-specific management strategies for the improvement of resource conditions and 2) to investigate broad-scale patterns in the status of different rangeland ecological sites across the entire Monument. The second objective is the focus of this paper. This case study illustrates an extensive application of the IIRH technique, and results provide insights into factors affecting patterns and processes of rangeland degradation.

\section{METHODS}

\section{Study Area}

The Monument covers approximately 760000 ha in southern Utah and the west-central portion of the Colorado Plateau physiographic province (Hunt 1974) between lat $37^{\circ} \mathrm{N}$, lat $38^{\circ} \mathrm{N}$, long $111^{\circ} \mathrm{W}$, and long $112.5^{\circ} \mathrm{W}$. Elevation ranges from 1164 to $2625 \mathrm{~m}$, and mean annual precipitation (MAP; 19611990) ranges from 17 to $61 \mathrm{~cm}$. (Precipitation estimates are based on the PRISM model, http://www.ocs.orst.edu/prism; Daly et al. 1994.) Approximately $90 \%$ of the Monument receives less than $36 \mathrm{~cm}$ MAP. As a proportion of MAP, MaySeptember precipitation varies from 33.1\% in Kanab (1509 m elevation, $37.9 \mathrm{~cm}$ MAP, $16 \mathrm{~km}$ west of the Monument boundary) to $44.2 \%$ in Escalante (1771 m elevation, $25.4 \mathrm{~cm}$ MAP, north-central edge of the Monument). Tremendous geologic and topographic heterogeneity (Doelling et al. 2000), as well as gradients in elevation and precipitation, together are responsible for generating a diversity of soils and ecological settings across the Monument. In a recent soil survey for the Monument, the NRCS described 136 distinct soil types and 50 distinct ecological sites (NRCS 2005).

Livestock grazing has been an important economic activity on lands within the Monument since the time of EuroAmerican settlement in the 1870s (Bradley 1999), and it remains the most extensive land use on the Monument today. Monument lands are subdivided into 91 grazing allotments, some of which extend onto adjoining public lands managed by the NPS (Glen Canyon National Recreation Area) and the US Department of Agriculture Forest Service (Dixie National Forest). Allotments are divided into two or more fenced pastures to facilitate livestock management. Pastures represent the smallest management units in the Monument, although they are typically larger than 5000 ha and range in size up to 54288 ha.

\section{Sampling Design}

A major objective of the assessment project was to collect data that would contribute to an evaluation of resource conditions 
in grazing allotments and to the development of future strategies for meeting resource-management objectives. As a consequence, assessments were conducted in all pastures and allotments across the Monument. Within these management units, it was assumed that ecosystem conditions could vary among different soils and ecological sites due to potential differences in past livestock use and in ecosystem responses to livestock use, management activities, and climate variability. Thus digital spatial data delineating soils and ecological sites were used to stratify each pasture into soil-based sampling units.

Within sampling units in pastures, specific assessment locations were identified subjectively rather than probabilistically. This approach was chosen because time and resources were judged to be inadequate for obtaining a statistically adequate number of randomly located assessments for each sampling unit in all pastures and allotments, given the overall scope of the project. For each pasture, soil map units were ranked in descending order according to their total area in the pasture, and at least one assessment was conducted in the predominant ecological site in the soil map units that cumulatively accounted for at least $75 \%$ of the pasture area. Assessments also were conducted in areas expected to receive relatively high livestock use even where these areas were associated with minor soil components or soil map units that fell below the $75 \%$ cut-off in a particular pasture. Water sources and similar areas with concentrated livestock use were excluded from sampling. The assessment team selected one or more representative assessment locations associated with each targeted ecological site, with representativeness evaluated by examining aerial photographs with superimposed soil map unit delineations and by surveying conditions on the ground prior to conducting assessments. Assessment locations were approximately $0.5-1.0$ ha in size.

\section{Field Methods}

Assessments were conducted following the technique IIRH, version 3 (Pellant et al. 2000; Pyke et al. 2002). The standard technique calls for the evaluation of three ecosystem attributes (soil/site stability, hydrologic function, and biotic integrity; Table 1 ) on the basis of 17 qualitative indicators (Pellant et al. 2000; Pyke et al. 2002; Table 2). Indicators and attributes for a particular assessment area are evaluated and rated according to the degree to which they depart from benchmark (reference) conditions described in ecological site descriptions prepared by NRCS and/or observed at one or more ecological reference areas (Pellant et al. 2000; Pyke et al. 2002), and on the basis of the combined experience and professional judgment of the interdisciplinary assessment team. In all cases, benchmark conditions are identified and applied on an ecological-site basis, thus requiring assessment teams to properly identify soil types and ecological sites. An ordinal, five-class rating system is used, with degree of departure rated as none to slight (NS), slight to moderate $(\mathrm{SM})$, moderate $(\mathrm{M})$, moderate to extreme $(\mathrm{ME})$, or extreme (E). In the project described here, assessment teams identified relatively few reference areas. Thus ratings primarily were based on NRCS ecological site descriptions for those indicators related to plant community composition, ground cover, and potential primary production. For indicators not described in existing site descriptions (e.g., frequency and
Table 1. Three attributes of rangeland health and their definitions (from Pellant et al. 2000; Pyke et al. 2002).

\begin{tabular}{ll}
\hline \multicolumn{1}{c}{ Attribute } & \multicolumn{1}{c}{ Definition } \\
\hline Soil/site stability & $\begin{array}{c}\text { The capacity of a site to limit redistribution and loss } \\
\text { of soil resources (including nutrients and organic } \\
\text { matter) by wind and water. } \\
\text { The capacity of a site to capture, store, and safely } \\
\text { release water from rainfall, run-on, and snowmelt } \\
\text { (where relevant), to resist a reduction in this } \\
\text { capacity, and to recover this capacity following } \\
\text { degradation. } \\
\text { Capacity of a site to support characteristic } \\
\text { functional and structural communities in the } \\
\text { context of normal variability, to resist loss of this } \\
\text { function and structure due to a disturbance, and } \\
\text { to recover following such disturbance. }\end{array}$ \\
\hline
\end{tabular}

spatial distribution of erosional features such as rills, pedestals, and terracettes), indicator ratings primarily were based on team members' collective field observations and experience. Interdisciplinary assessment teams ranged in size from two to five members, with botanists, ecologists, geologists, wildlife biologists, and rangeland management specialists serving as the primary team members.

The IIRH protocol allows for the use of additional indicators where necessary to meet local assessment needs (Pellant et al. 2000). For this project, the integrity of biological soil crusts (BSCs) was included as an 18th indicator applicable to all three ecosystem attributes (Table 2) because of important BSC contributions to soil stabilization (Belnap 1995; Williams et al. 1995a, 1995b), hydrologic processes (Warren 2003; Belnap et al. 2005), nutrient cycling (Evans and Lange 2003), and biological diversity (Rosentreter and Belnap 2003) in rangeland ecosystems on the Colorado Plateau. Ratings for this indicator were based on the distribution and abundance of soil lichens, soil mosses, and dark cyanobacterial crusts in comparison with reference areas and team members' collective field observations and experience (Table 3). During the 2002 field season, ratings for biological soil crusts also were informed by preliminary results from a concurrent project being conducted to develop a spatial predictive model of BSC cover, composition, and function in relation to precipitation and substrate characteristics (Bowker et al. 2006).

To inform the evaluation of qualitative indicators and increase consistency of the assessment process, quantitative data on ground cover (e.g., percentage of cover of bare ground/mineral soil, BSC, litter, plant bases, and rock), plant community composition (percentage of live and dead canopy and basal cover by species and plant functional groups), and soil stability were collected prior to evaluating indicators and attributes (Pyke et al. 2002). Data on ground cover and plant community composition were collected following the steppoint technique (Coulloudon et al. 1999). Cover data were recorded for 50-100 subsample points (approximately 1-mm diameter) placed at 4-pace intervals along a pace transect walked by one or two team members. The pace transect crossed the assessment area three to five times, with total transect length ranging from 150 to $300 \mathrm{~m}$. Surface and subsurface soil stability 
Table 2. Brief description of 18 rangeland health indicators, their applicability to rangeland health attributes, and associated quantitative data collected during assessments conducted on Grand Staircase-Escalante National Monument (adapted from Pyke et al. 2002).

\begin{tabular}{|c|c|c|c|c|}
\hline \multirow[b]{2}{*}{ Indicator and brief description } & \multicolumn{3}{|c|}{ Attributes $^{1}$} & \multirow[b]{2}{*}{ Quantitative data } \\
\hline & $\mathrm{S}$ & $\mathrm{H}$ & B & \\
\hline 1. Rills - frequency and spatial distribution of linear erosional rivulets & $x$ & $\mathrm{X}$ & - & - \\
\hline $\begin{array}{l}\text { 2. Water flow patterns - amount and distribution of overland flow paths that are identified by litter } \\
\text { distribution and visual evidence of soil and gravel movement }\end{array}$ & $\mathrm{X}$ & $\mathrm{X}$ & - & - \\
\hline $\begin{array}{l}\text { 3. Pedestals and/or terracettes - frequency and distribution of rocks or plants where soil has been eroded } \\
\text { from their base (pedestals), and/or occurrence of erosional terracettes }\end{array}$ & $x$ & $x$ & - & - \\
\hline $\begin{array}{l}\text { 4. Bare ground - size and connectivity among areas of soil not protected by vegetation, biological soil } \\
\text { crusts, litter, standing dead vegetation, gravel, or rocks }\end{array}$ & $\mathrm{X}$ & $x$ & - & Percentage of bare ground \\
\hline $\begin{array}{l}\text { 5. Gullies - amount of channels cut into the soil and the amount and distribution of vegetation in the } \\
\text { channel }\end{array}$ & $x$ & $\mathrm{x}$ & - & - \\
\hline $\begin{array}{l}\text { 6. Wind-scoured areas, blowouts, and/or deposition areas - frequency of areas where soil is removed from } \\
\text { under physical or biological soil crust or around vegetation OR frequency of accumulation areas of soil } \\
\text { associated with large structural objects, often woody plants }\end{array}$ & $x$ & - & - & - \\
\hline 7. Litter movement - frequency and size of litter displaced by wind and overland flow of water & $\mathrm{X}$ & - & - & - \\
\hline $\begin{array}{l}\text { 8. Soil surface resistance to erosion - ability of soils to resist erosion through the incorporation of organic } \\
\text { material into soil aggregates }\end{array}$ & $\mathrm{x}$ & $x$ & $\mathrm{X}$ & Soil aggregate stability \\
\hline $\begin{array}{l}\text { 9. Soil surface loss or degradation - frequency and size of areas missing all or portions of the upper soil } \\
\text { horizons that normally contain the majority of organic material of the site }\end{array}$ & $\mathrm{X}$ & $\mathrm{X}$ & $\mathrm{X}$ & - \\
\hline $\begin{array}{l}\text { 10. Plant community composition and distribution relative to infiltration and runoff - the community } \\
\text { composition or distribution of species that restrict the infiltration of water on the site }\end{array}$ & - & $\mathrm{X}$ & - & $\begin{array}{l}\text { Percentage of composition by } \\
\text { functional group }\end{array}$ \\
\hline $\begin{array}{l}\text { 11. Compaction layer - thickness and distribution of the structure of the soil near the soil surface } \\
(\leq 15 \mathrm{~cm})\end{array}$ & $\mathrm{X}$ & $\mathrm{X}$ & $\mathrm{X}$ & - \\
\hline $\begin{array}{l}\text { 12. Functional / structural groups - the number of groups, the number of species within groups, or the rank } \\
\text { of order of dominance of groups }\end{array}$ & - & - & $\mathrm{X}$ & $\begin{array}{l}\text { Relative composition and } \\
\text { dominance of functional groups } \\
\text { (based on cover) }\end{array}$ \\
\hline 13. Plant mortality/decadence - frequency of dead or moribund (dying) plants & - & - & $\mathrm{X}$ & Percentage of standing-dead cover \\
\hline 14. Litter amount - deviation in the amount of litter & - & $x$ & $\mathrm{X}$ & Percentage of cover of litter \\
\hline $\begin{array}{l}\text { 15. Annual aboveground production - amount relative to the potential for that year based upon recent } \\
\text { climatic conditions }\end{array}$ & - & - & $\mathrm{X}$ & - \\
\hline $\begin{array}{l}\text { 16. Invasive plants - abundance and distribution of invasive plants regardless if they are noxious weeds, } \\
\text { exotic species, or native plants whose dominance greatly exceeds that expected for the ecological } \\
\text { site }\end{array}$ & - & - & $\mathrm{X}$ & $\begin{array}{l}\text { Percentage of cover and relative } \\
\text { composition of invasive plants }\end{array}$ \\
\hline $\begin{array}{l}\text { 17. Reproductive capability of perennial plants - evidence of the inflorescences or of vegetative tiller } \\
\text { production relative to the potential for that year based upon recent climatic conditions }\end{array}$ & - & - & $\mathrm{X}$ & - \\
\hline 18. Biological soil crusts - amount, spatial distribution, and degree of development & $x$ & $\mathrm{X}$ & $\mathrm{X}$ & $\begin{array}{l}\text { Percentage of cover and relative } \\
\text { composition of biological soil } \\
\text { crusts }\end{array}$ \\
\hline
\end{tabular}

${ }^{1} \mathrm{~S}$ indicates soil/site stability; H, hydrologic function; and B, biotic integrity.

beneath plant canopies and in interspaces among plants was measured using a soil aggregate stability field kit (Herrick et al. 2001). Nine pairs of surface and subsurface samples were collected from three to six interspace locations and three to six subcanopy locations that were selected as visually representative of conditions across the assessment area.
Assessments were conducted from July 2000 through December 2002 , with about $80 \%$ of the field work conducted during April-October periods in 2001 and 2002. Amounts of precipitation received in Kanab and Escalante respectively were $32 \%$ and $43 \%$ below the 1971-2000 average during the 2000 water year, $13 \%$ and $27 \%$ above average during the 2001

Table 3. Evaluation matrix for biological soil crusts (from Pellant et al. 2000).

\begin{tabular}{|c|c|c|c|c|c|}
\hline \multirow[b]{2}{*}{ Indicator } & \multicolumn{5}{|c|}{ Degree of departure from ecological site description and/or ecological reference area(s) } \\
\hline & Extreme & Moderate to extreme & Moderate & Slight to moderate & None to slight \\
\hline Biological soil crusts & $\begin{array}{l}\text { Found only in protected } \\
\text { areas; very limited suite } \\
\text { of functional groups }\end{array}$ & $\begin{array}{l}\text { Largely absent, occurring } \\
\text { mostly in protected } \\
\text { areas }\end{array}$ & $\begin{array}{l}\text { In protected areas and } \\
\text { with a minor component } \\
\text { in interspaces }\end{array}$ & $\begin{array}{l}\text { Evident throughout the } \\
\text { site, but continuity is } \\
\text { broken }\end{array}$ & $\begin{array}{l}\text { Largely intact and nearly } \\
\text { matches site capability }\end{array}$ \\
\hline
\end{tabular}


water year, and $53 \%$ and $64 \%$ below average during the 2002 water year (Western Regional Climate Center 2007).

\section{Data Analyses}

Chi-square analysis (Zar 1999) was used to examine whether the three attributes of rangeland health had different rating distributions for all assessment locations combined (507 assessments and 1521 attribute ratings). For ecological sites with five or more assessments, $\chi^{2}$ analyses also were used to determine whether some ecological sites were characterized by ecosystem conditions that were better (i.e., a greater proportion of assessments with a small degree of departure from expected reference conditions) or worse (greater proportion of assessments with a large degree of departure from expected reference conditions) than typical conditions described on the basis of the combined data set for all 507 assessment locations. For each ecological site, separate $\chi^{2}$ analyses were conducted for each of the three attributes of rangeland health.

Extensive areas within the Monument were mechanically treated in the past to reduce the cover of unpalatable woody vegetation such as big sagebrush (Artemisia tridentata Nuttall), Utah juniper (Juniperus osteosperma [Torrey] Little), and Colorado pinyon (Pinus edulis Engelmann). In conjunction with mechanical treatments, treated areas (hereafter referred to as "seedings") generally were seeded with nonnative forage grasses such as crested wheatgrass (Agropyron cristatum [L.] Gaertner) and Russian wildrye (Elymus junceus Fischer). (Taxonomic nomenclature follows Welsh et al. 2003.) For ecological sites with five or more assessments in seedings and in comparable untreated areas, separate $\chi^{2}$ analyses were conducted to examine whether there was a tendency for seedings or untreated areas to be characterized by better or worse ecosystem conditions in comparison with all 507 assessments combined. For all $\chi^{2}$ analyses, rating classes $\mathrm{E}$ and ME were combined into a single class (E-ME) because of the infrequent occurrence of $\mathrm{E}$ ratings. Multivariate analysis of variance (MANOVA) also was used to test for differences between mean values of selected quantitative measures for seeded and comparable untreated ecological sites. Dependent variables were $\log$-transformed $\left[x^{\prime}=\ln (x+1)\right]$ prior to analysis because variances were proportional to means (Zar 1999). Stepwise multiple regression analysis was used to examine potential factors contributing to general patterns in ecosystem condition among ecological sites (Zar 1999).

Ecosystems dominated by varieties of big sagebrush are of particular interest to resource managers on the Colorado Plateau and throughout the Intermountain West because of their diversity and habitat value, and because they have been widely degraded by cumulative effects of land use, invasive exotic plants, and altered fire regimes (Knick et al. 2003; Connelly et al. 2004; Welch 2005). Five of the 50 distinct ecological sites found in the Monument are characterized by potential vegetation dominated by varieties of big sagebrush (Table 4; NRCS 2005). Of these five sites, the Semidesert Loam (Wyoming big sagebrush) site had a relatively large sample size $(n=55)$ and was characterized by a wide range of rangelandhealth conditions. For these reasons, data for this ecological site were examined in greater detail to evaluate relationships between quantitative data and qualitative ratings of rangeland health. Principal components analysis (PCA; McCune and
Grace 2002) with varimax normalized factor rotation was used to describe variability among the 55 assessments in terms of 12 quantitative variables: interspace soil aggregate stability; percentage of total live cover; total plant cover; percentage of bare ground; percentage of BSC cover; percentage of litter cover; percentage of relative cover of annual exotic plants, total exotic plants, and woody plants; functional group richness; diversity $\left(\mathrm{H}^{\prime}\right)$; and evenness (J'; Zar 1999). Spearman's rank correlation coefficients (Zar 1999) were calculated to describe relationships between quantitative variables and ordinal qualitative ratings assigned to the three rangeland-health attributes. MANOVA was used to test whether log-transformed mean values for selected quantitative variables were significantly different among rating classes for individual rangeland health attributes. For rangeland health attributes determined to have significant effects by MANOVA, Tukey's honestly significant difference (HSD) post hoc analysis was used to test for differences between mean quantitative measures associated with different attribute rating classes (Zar 1999). With the exception of the $\chi^{2}$ analyses, all statistical analyses were conducted using the software package STATISTICA ${ }^{\text {TM }}$ version 6.1 on a Windows ${ }^{\circledR}$ platform (Statsoft 2004). For all analyses, results with $P \leq 0.05$ were considered statistically significant.

\section{RESULTS}

\section{Overall Patterns Among Ecological Sites}

For all 507 assessments combined, SM was the modal rating class for each of the three rangeland health attributes (Fig. 1). The rating distributions for all three attributes were similar, but the distribution for biotic integrity was significantly different than the distribution for all 1521 attribute ratings combined. Overall, biotic integrity tended to receive NS ratings less frequently and $\mathrm{M}$ and SM ratings more frequently than soil/site stability and hydrologic function attributes (Fig. 1). Of the 507 assessments, $226(44.6 \%)$ were assigned a low rating (moderate or greater departure from expected reference conditions) for at least one of the three attributes, and $100(19.7 \%)$ were assigned low ratings for all three attributes.

Of the 26 ecological sites with five or more assessments (including seeded and untreated areas for two ecological sites), 10 had one or more attributes with rating distributions that were significantly different than the overall distributions for all 507 assessments (Tables 4 and 5). Of the five ecological sites with significantly higher frequencies of low ratings relative to the overall distributions, four were deep-soil ecological sites with high potential production and potential vegetation dominated by varieties of big sagebrush (Tables 4 and 5). In contrast, all five ecological sites with significantly lower frequencies of low ratings relative to the overall distributions were shallow-soil ecological sites with relatively low potential production and potential vegetation characterized by the presence of juniper and/or pinyon. Only the seeded Upland Loam and seeded and untreated Semidesert Loam ecological sites had rating distributions that were significantly different from overall distributions for all three rangeland health attributes. Potential dry-weight production (Table $4 ; \beta=0.447$, $P=0.003$ ) and treatment (seeded vs. untreated, from Table 4; 


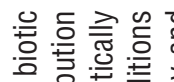

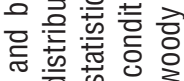

들 을 을

흘

政

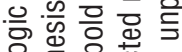

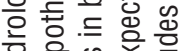

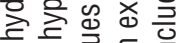

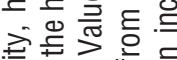

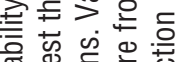

跑

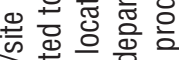

言产

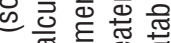

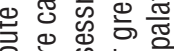

言嘀

क

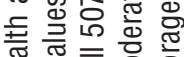

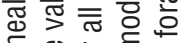

흠흔흥 흥

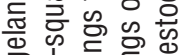

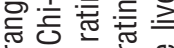

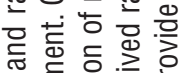

응

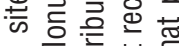

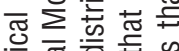

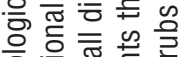

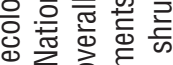

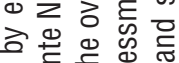

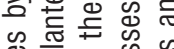

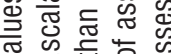

3)

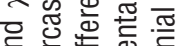

的率

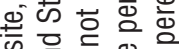

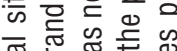

政

응

8 \&

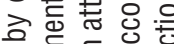

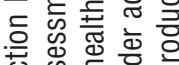

든

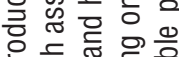

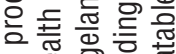

흘 흘 행

휭

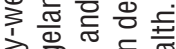

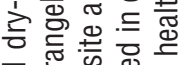

要

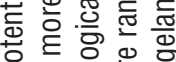

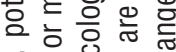

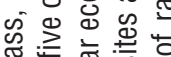

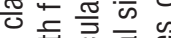

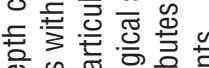

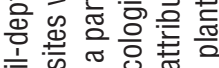

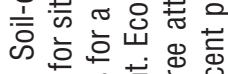

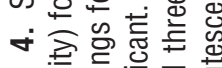

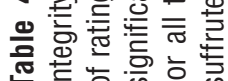

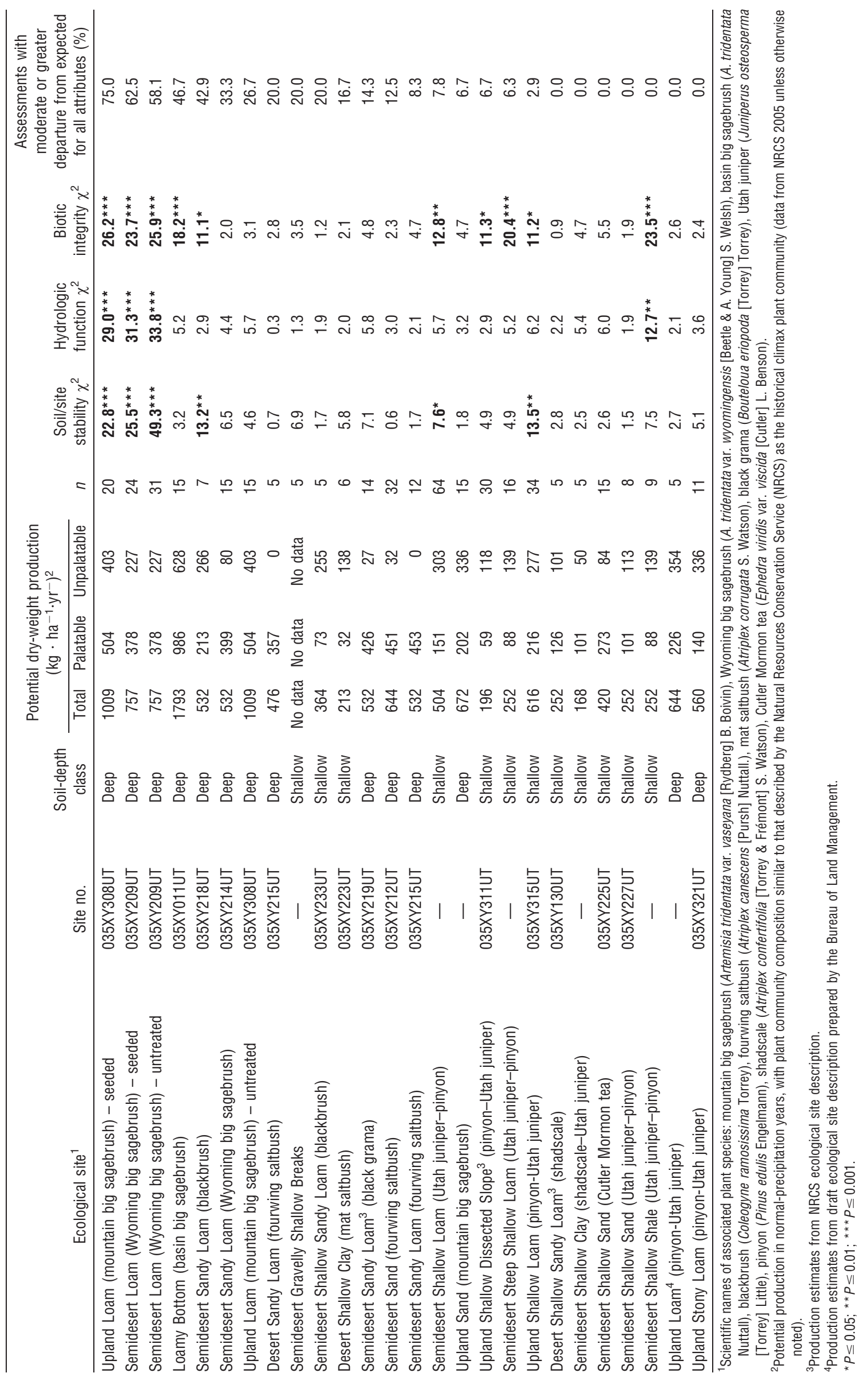




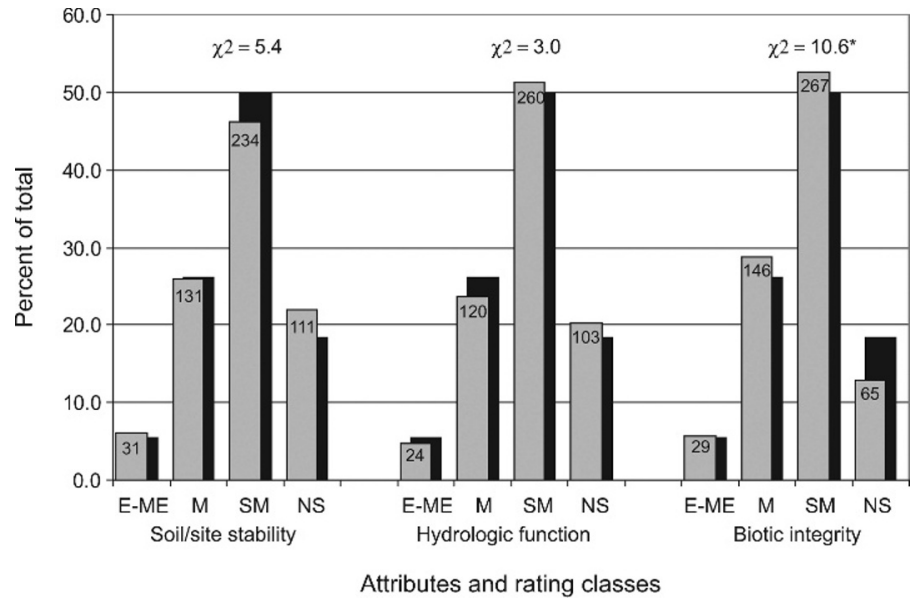

Figure 1. Overall distributions (gray bars) of ratings assigned to three rangeland-health attributes at 507 assessment locations on Grand Staircase-Escalante National Monument. Numerals in gray bars indicate numbers of assessments that received associated ratings. Black bars behind each rating distribution indicate the overall distribution of all 1521 ratings and the null distributions that were used in $\chi^{2}$ analyses for each of the three attributes (reflected by $\chi^{2}$ statistics above each rating distribution; ${ }^{*} P<0.05$ ). For attribute ratings, $\mathrm{E}$ indicates extreme departure; ME, moderate to extreme departure; M, moderate departure; SM, slight to moderate departure; and NS, no departure to slight departure from expected reference conditions.

$\beta=0.556, P=0.0004)$ both were significant in a stepwise multiple regression model predicting for each ecological site the percentage of assessment locations that was assigned low ratings for all three attributes of rangeland health (adjusted $R^{2}=0.62, \mathrm{df}$ 2,22, $F=20.34, P=0.00001)$. Log-transformed means for percentage of bare ground, BSC cover, and interspace soil aggregate stability were not significantly different between seeded and untreated Semidesert Loam (Wilks' $\lambda=0.94, F=0.94$, df $3,46, P=0.43$ ) and Upland Loam (Wilks' $\lambda=0.84, F=1.70, \mathrm{df}$ $3,27, P=0.19)$ ecological sites.
Patterns Within the Semidesert Loam Ecological Site

Two PCA axes explain $49.3 \%$ of the variability in 12 quantitative variables sampled in conjunction with 55 assessments of the Semidesert Loam ecological site (seeded and untreated areas combined; Fig. 2). Axis 1 represents a gradient of decreasing bare ground and increasing total plant cover, total live cover, and functional group richness and diversity (Fig. 2a). Axis 2 represents a gradient of decreasing relative cover of exotic plants (including nonnative forage grasses, which accounted for $72.0 \%$ of total exotic cover, on average) and increasing interspace soil aggregate stability and cover of BSCs (Fig. 2a). Qualitative ratings assigned to the three attributes of rangeland health tended to be higher (lesser degree of departure from expected reference conditions) at assessment locations characterized by higher scores for PCA axes 1 and 2, but there was considerable variability in PCA scores among assessment locations that were assigned the same qualitative rating for a particular attribute (Figs. 2b-2d). Ratings for the three attributes of rangeland health were more strongly correlated with site scores for PCA axis 2 than with site scores for PCA axis 1 (Table 6).

Seven of twelve quantitative variables were significantly correlated with ratings assigned for one or more rangeland health attributes (Table 6). Measures of functional group richness and diversity $\left(\mathrm{H}^{\prime}\right)$ were important in the PCA but not correlated with assigned ratings for any of the three attributes (Table 6). However, both variables were significantly correlated with assigned ratings for the individual indicator pertaining to functional and structural groups (richness: $\rho=0.42, P<0.01$; diversity: $\rho=0.38, P<0.01)$. Percentage of bare ground, total live cover, BSC cover, and interspace soil aggregate stability had the highest rank correlations with assigned attribute ratings (Table 6). MANOVA results for these four variables were statistically significant for each of the three rangeland health attributes (soil/site stability: Wilks' $\lambda=0.26, F=6.28$, effect $\mathrm{df}=12$, error $\mathrm{df}=114.1, P<0.001$; hydrologic function: Wilks' $\lambda=0.29, F=5.63$, effect $\mathrm{df}=12$,

Table 5. Percentages of assessments by rating class $^{1}$ for three rangeland health attributes (soil/site stability, hydrologic function, and biotic integrity) at 10 rangeland ecological sites and for all sites combined, Grand Staircase-Escalante National Monument. Values are only reported for those ecological sites and attributes with rating distributions that are significantly different than the associated distribution for all sites combined (see Table 4 for significant $\chi^{2}$ values). Bold, underlined print indicates percentages that exceed corresponding percentages for all sites combined.

\begin{tabular}{|c|c|c|c|c|c|c|c|c|c|c|c|c|c|}
\hline \multirow[b]{2}{*}{ Ecological site } & \multirow[b]{2}{*}{$n$} & \multicolumn{4}{|c|}{ Soil/site stability } & \multicolumn{4}{|c|}{ Hydrologic function } & \multicolumn{4}{|c|}{ Biotic integrity } \\
\hline & & $\mathrm{E}-\mathrm{ME}$ & M & SM & NS & E-ME & M & SM & NS & E-ME & M & SM & NS \\
\hline All sites combined & 507 & 6.1 & 25.8 & 46.2 & 21.9 & 4.7 & 23.7 & 51.3 & 20.3 & 5.7 & 28.8 & 52.7 & 12.8 \\
\hline Upland Loam (mountain big sagebrush) - seeded & 20 & $\underline{20.0}$ & 60.0 & 20.0 & 0.0 & $\underline{20.0}$ & $\underline{60.0}$ & 20.0 & 0.0 & 5.0 & 80.0 & 15.0 & 0.0 \\
\hline Semidesert Loam (Wyoming big sagebrush) - seeded & 24 & $\overline{16.7}$ & $\overline{62.5}$ & 20.8 & 0.0 & $\overline{16.7}$ & $\overline{62.5}$ & 16.7 & 4.2 & 25.0 & $\overline{45.8}$ & 29.2 & 0.0 \\
\hline Semidesert Loam (Wyoming big sagebrush) - untreated & 31 & $\overline{35.5}$ & 29.0 & 19.4 & 16.1 & $\underline{22.6}$ & $\overline{45.2}$ & 22.6 & 9.7 & $\overline{22.6}$ & $\overline{48.4}$ & 22.6 & 6.5 \\
\hline Loamy Bottom (basin big sagebrush) & 15 & - & - & - & - & - & - & - & - & $\overline{13.3}$ & $\overline{73.3}$ & 13.3 & 0.0 \\
\hline Semidesert Sandy Loam (Blackbrush) & 7 & 0.0 & 85.7 & 14.3 & 0.0 & - & - & - & - & 0.0 & 85.7 & 14.3 & 0.0 \\
\hline Semidesert Shallow Loam (Utah juniper-pinyon) & 64 & 1.6 & $\overline{17.2}$ & $\underline{48.4}$ & $\underline{32.8}$ & - & - & - & - & 0.0 & $\overline{14.1}$ & $\underline{67.2}$ & $\underline{18.8}$ \\
\hline Upland Shallow Dissected Slope (pinyon-Utah juniper) & 30 & - & - & - & - & - & - & - & - & 3.3 & 3.3 & $\overline{80.0}$ & $\overline{13.3}$ \\
\hline Semidesert Steep Shallow Loam (Utah juniper-pinyon) & 16 & - & - & - & - & - & - & - & - & 0.0 & 12.5 & 37.5 & $\underline{50.0}$ \\
\hline Upland Shallow Loam (pinyon-Utah juniper) & 34 & 0.0 & 8.8 & 47.1 & 44.1 & - & - & - & - & 2.9 & 5.9 & $\underline{67.6}$ & 23.5 \\
\hline Semidesert Shallow Shale (Utah juniper-pinyon) & 9 & - & - & - & $\overline{-}$ & 0.0 & 0.0 & 33.3 & 66.7 & 0.0 & 11.1 & $\overline{22.2}$ & $\overline{66.7}$ \\
\hline
\end{tabular}

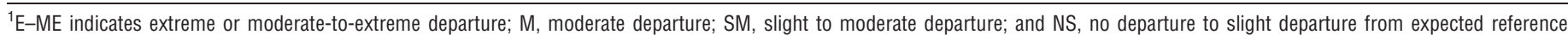
conditions. 

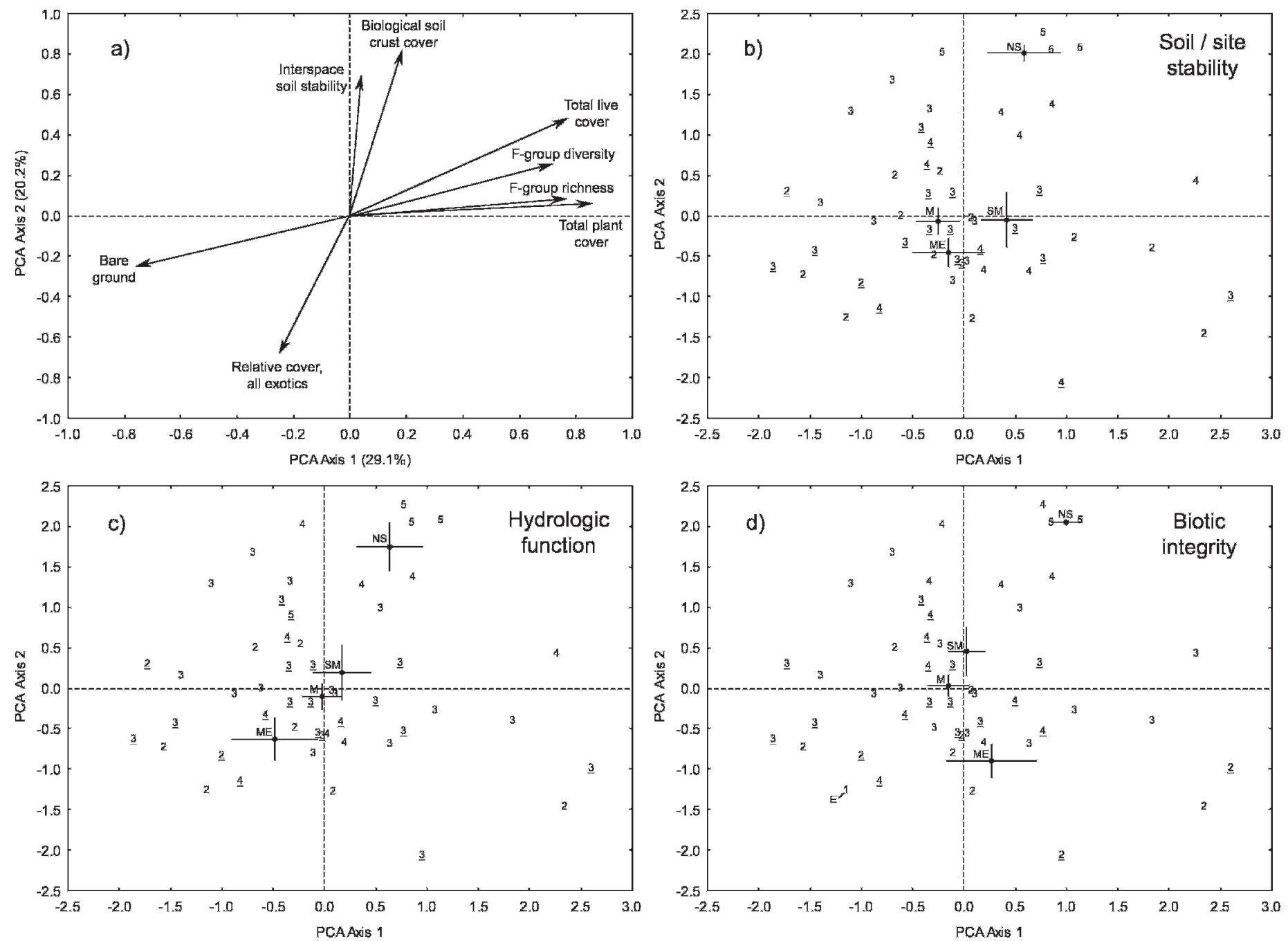

Figure 2. Principal components analysis (PCA) results for data associated with 12 quantitative variables measured at 55 Semidesert Loam assessment locations, Grand Staircase-Escalante National Monument. a, vectors indicate loadings (Pearson correlation coefficients, $r$ ) of eight variables on axes 1 and 2 (only those variables with $r \geq 0.60$ are shown; F-group indicates functional group). In the remaining panels, numbers $1-5$ indicate attribute ratings (1 and E indicate extreme departure; 2 and ME, moderate to extreme departure; 3 and M, moderate departure; 4 and SM, slight to moderate departure; and 5 and NS, no departure to slight departure from expected reference conditions) assigned for $\mathbf{b}$, soil/site stability; $\mathbf{c}$, hydrologic function; and $\mathbf{d}$, biotic integrity at each of the assessment locations. Underlined ratings are for assessments associated with seedings. Coordinates of the attribute ratings in ordination space indicate PCA scores associated with the corresponding assessment location. Points indicate centroids (mean PCA scores $\pm 1 \mathrm{SE}$ ) for each set of assessment locations receiving the same attribute rating.

error $\mathrm{df}=114.1, P<0.001$; biotic integrity: Wilks' $\lambda=0.32$, $F=3.62$, effect $\mathrm{df}=16$, error $\mathrm{df}=128.9, \quad P<0.001$ ), but Tukey's HSD analyses found relatively few significant differences among log-transformed mean values for different attribute rating classes because of the high degree of variability in quantitative measures among assessments that were assigned the same rating for a particular attribute (Fig. 3). Mean quantitative measures for assessment locations that were assigned NS ratings for rangeland health attributes were statistically different than means associated with locations that were assigned lower rangeland health ratings in most cases, whereas means for locations that were assigned ME, M, or SM ratings were statistically different from one another less frequently (Fig. 3). This finding is consistent with PCA results showing that centroids for locations that were assigned ME, $M$, or SM ratings tended to be clustered together in the center of the ordination space defined by the quantitative variables, whereas the centroids for locations assigned NS ratings were relatively distinct in ordination space (Fig. 2).

\section{DISCUSSION}

Results of this broad-scale assessment project indicate patterns in qualitative attributes and quantitative measures of rangeland health across a 760000 -ha landscape that represents a significant proportion of the Colorado Plateau physiographic province. Because of the large numbers of assessment locations and ecological sites included in the project, data resulting from this effort represent a valuable resource for examining general patterns in ecosystem condition among and within different ecological sites, and for developing hypotheses about factors 
Table 6. Spearman rank correlations between 12 quantitative variables included in the principal components analysis (PCA; Fig. 2), site scores for PCA axes 1 and 2, and ordinal qualitative ratings (extreme, moderate-toextreme, moderate, slight-to-moderate, and none-to-slight departure from expected reference conditions ranked 1-5, respectively) for rangeland health attributes soil/site stability, hydrologic function, and biotic integrity at 55 Semidesert Loam assessment locations on Grand StaircaseEscalante National Monument $(n=50$ for interspace soil aggregate stability). Bold type indicates statistically significant relationships.

\begin{tabular}{|c|c|c|c|}
\hline Variable & $S$ & $\mathrm{H}$ & B \\
\hline Bare ground $\%$ & $-0.65^{* * *}$ & $-0.65^{\star \star *}$ & $-0.40^{* *}$ \\
\hline Total live cover \% & $0.54^{* * *}$ & $0.55^{* * *}$ & $0.48^{* * *}$ \\
\hline Total plant cover $\%$ & $0.35^{* *}$ & 0.38 ** & $0.31^{*}$ \\
\hline Biological soil crust cover \% & $0.52^{* * *}$ & $0.47^{\star * *}$ & $0.57^{* * *}$ \\
\hline Litter cover \% & 0.16 & 0.19 & 0.15 \\
\hline Interspace soil aggregate stability & $0.50^{* * *}$ & $0.40^{* *}$ & $0.50^{* * *}$ \\
\hline Functional group richness & 0.09 & 0.19 & 0.19 \\
\hline Functional group diversity $\left(\mathrm{H}^{\prime}\right)$ & 0.15 & 0.24 & 0.17 \\
\hline Functional group evenness $\left(\mathrm{J}^{\prime}\right)$ & 0.05 & 0.02 & -0.15 \\
\hline Relative annual exotic cover $\%$ & 0.01 & -0.10 & $-0.42^{\star *}$ \\
\hline Relative total exotic cover \% & -0.18 & -0.20 & $-0.31^{*}$ \\
\hline Relative woody plant cover $\%$ & -0.05 & -0.06 & -0.11 \\
\hline PCA axis 1 site scores & $0.33^{*}$ & $0.33^{*}$ & 0.13 \\
\hline PCA axis 2 site scores & 0.38 ** & $0.42^{\star *}$ & $0.58^{* * *}$ \\
\hline
\end{tabular}

${ }^{1} \mathrm{~S}$ indicates soil/site stability; $\mathrm{H}$, hydrologic function; and $\mathrm{B}$, biotic integrity. ${ }^{\star} P \leq 0.05 ;{ }^{* *} P \leq 0.01 ;{ }^{* *} P \leq 0.001$.

that may have contributed to the development of these patterns.

\section{Factors Contributing to Patterns Among Ecological Sites}

Production Potential and Relative Use. At the scale of the entire Monument, upland ecological sites with the greatest production potential tended to be the most degraded, as measured by percentages of assessment locations that were assigned low ratings for all three attributes of rangeland health. Productivity has been widely cited as a factor affecting ecosystem responses to grazing by large herbivores (Milchunas et al. 1988; Cingolani et al. 2005; Lunt et al. 2007) and to disturbance in general (Huston 1979). In the Monument, production potential likely was an indirect factor contributing to general patterns of ecosystem status among different ecological sites because of correlations with land use and plant community composition.

In this rocky dryland environment characteristic of much of the Colorado Plateau, ecological sites with the greatest production potential account for a relatively small proportion of the landscape and thus have tended to receive a disproportionate level of use for livestock grazing-the predominant production-oriented land-use activity on the Monument. For example, estimates based on soil-survey data (NRCS 2005) indicate that productive Upland Loam, Semidesert Loam, and Loamy Bottom ecological sites cumulatively account for approximately $7.4 \%$ (56461 ha) of the total Monument area. In contrast, relatively unproductive ecological sites with low frequencies of low rangeland health ratings (those with signficant $\chi^{2}$ values in Table 4) account for approximately $33.8 \%$ (257378 ha) of the total Monument area. Relative to the productive big sagebrush ecological sites, the unproductive ecological sites typically have received low levels of use for livestock grazing or other land-use activities except on a very localized basis. On the basis of existing data, it is difficult to quantify differences in livestock use among ecological sites because use is recorded by allotment and allotment boundaries do not correspond with ecological site boundaries.

Plant Community Composition. The relative abundance of different plant functional types is an important factor that affects ecosystem responses to drivers such as livestock grazing (Díaz et al. 2002; Lunt et al. 2007). In the Monument, rangeland ecological sites with the greatest production potential are characterized by the presence of big sagebrush, with that species accounting for a significant proportion of standing biomass and annual production $(20 \%-30 \%)$ in historic climax plant communities described by NRCS (2005). Except for some formerly grazed reference areas and seedings where sagebrush was removed or thinned in the past, most assessments conducted in big sagebrush ecological sites found much higher ratios of sagebrush to perennial grasses than expected on the basis of NRCS ecological site descriptions-a factor that contributed to the assignment of low ratings for biotic integrity at such locations.

Big sagebrush is relatively unpalatable to livestock, and livestock grazing (selective herbivory) has long been cited as a process that has facilitated increases in shrub:grass ratios in sagebrush ecological sites throughout the Intermountain West due to effects of grass removal on competitive relations and fire frequency (USDA Forest Service 1937; Miller et al. 1994). But successional trends resulting in increasing shrub:grass ratios have been reported for ungrazed sagebrush ecosystems in some settings, a pattern that may be attributable to landscape characteristics that naturally protect such sites from fire (West and Yorks 2006). Baker (2006) reviewed the evidence for natural fire regimes in sagebrush ecosystems and concluded that fire exclusion (whether due to grazing or fire suppression) probably has had little effect on vegetation trends in most sagebrush systems because of natural fire-return intervals that are likely to be much longer than commonly assumed. In a study conducted on the Monument, Harris et al. (2003) found significantly higher sagebrush:grass ratios in a grazed area relative to a comparable area on an ungrazed mesa top (both associated with the Upland Loam [mountain big sagebrush] ecological site), suggesting that livestock grazing has played a role in increasing shrub:grass ratios in some settings.

No matter the cause, increases in shrub density can be accompanied by a greater concentration of soil impacts in interspaces among shrubs if such areas are used by livestock and/or large numbers of mule deer (Odocoileus hemionus). In many sagebrush-dominated areas associated with the Semidesert Loam ecological site in the Monument, trampling of interspaces has resulted in erosion and the loss of relatively sandy surface horizons, the exposure of relatively fine-textured subsurface horizons, and the subsequent development of "playettes" (Eckert et al. 1986) with vesicular structure (M. Miller, personal observation, August 2001). Interspace playettes have been reported for sagebrush settings elsewhere (Eckert et al. 1986; Pierson et al. 1994), and their presence can indicate altered hydrologic functioning (i.e., transition from 

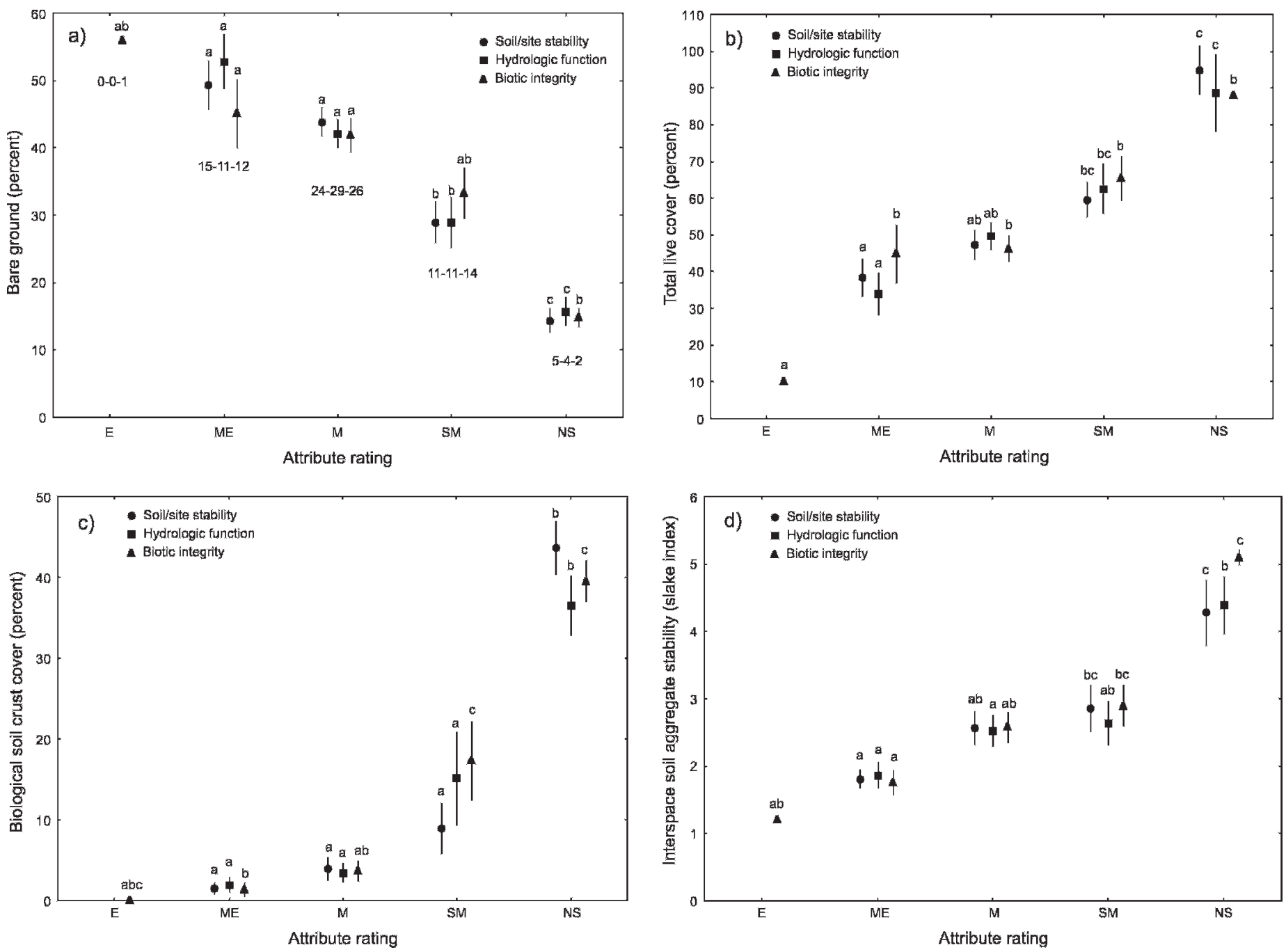

Figure 3. Relations between qualitative ratings assigned for rangeland health attributes (soil/site stability, hydrologic function, and biotic integrity) and quantitative measures (means $\pm 1 \mathrm{SE}$ ) of $\mathbf{a}$, percent bare ground; $\mathbf{b}$, percent total live cover; c, percent biological soil crust cover; and $\mathbf{d}$, interspace soil aggregate stability for 55 Semidesert Loam rangeland health assessments, Grand Staircase-Escalante National Monument. In a, numbers indicate sample sizes for multivariate analysis of variance and numbers of assessments that received particular ratings for particular attributes. For each quantitative measure and rangeland health attribute, means annotated with the same letter (a-d) are not significantly different. (Attribute ratings: E indicates extreme departure; ME, moderate to extreme departure; M, moderate departure; SM, slight to moderate departure; and NS, no departure to slight departure from expected reference conditions.)

infiltration to runoff generation; Pierson et al. 1994), accelerated erosion, and diminished potential for seedling establishment (Eckert et al. 1986). All of these were factors that contributed to low ratings for the three attributes of rangeland health.

Assessment results for big sagebrush ecological sites contrast with those for several ecological sites characterized by grassland physiognomic structure (Desert Sandy Loam [fourwing saltbush], Semidesert Sand [fourwing saltbush], Semidesert Sandy Loam [black grama], and Semidesert Sandy Loam [fourwing saltbush]). These grassland sites also tend to receive preferential use by livestock in the Monument because of high levels of forage production relative to production of unpalatable woody plants, but they all had lower frequencies of low rangeland health ratings than all of the big sagebrush ecological sites except the Upland Sand site (Table 4). This result may be due to the fact that these grassland ecological sites differ from many other semiarid grasslands (e.g., Van Auken 2000) in that they generally lack unpalatable, long-lived woody plants that have the capacity to increase and become persistent site dominants due to succession, absence of fire, or selective herbivory by livestock. In some settings where palatable shrubs such as winterfat (Ceratoides lanata [Pursh] J.T. Howell) and fourwing saltbush (Atriplex canescens [Pursh] Nuttall) are major components in these ecological sites, moderate livestock grazing actually tends to maintain grassland physiognomic structure whereas release from grazing can result in conversion to shrubland structure (Rasmussen and Brotherson 1986; Floyd et al. 2003).

Soil Texture. Among the five big sagebrush ecological sites, assessment results varied systematically in relation to soil texture. Sagebrush sites primarily associated with fine-loamy soils (seeded Upland Loam and seeded and untreated Semidesert Loam) had higher frequencies of assessments with low 
ratings for all rangeland health attributes than sites primarily associated with coarse-loamy (Loamy Bottom and Semidesert Sandy Loam [Wyoming big sagebrush]) or sandy (Upland Sand) soils (Table 4; soil textural family classes from NRCS 2005). Livestock grazing and trampling can have adverse impacts on rangeland hydrologic processes and erosion where they cause reductions in ground cover, soil aggregate stability, soil structure, and soil-surface roughness (Thurow 1991; Spaeth et al. 1996; Ward and Trimble 2004). Assessment results reported here for sagebrush ecological sites are consistent with Walker's (2002) proposition that relatively sandy soils are inherently more resistant to livestock impacts on hydrologic processes than soils with lots of silt and clay because infiltration rates are inherently greater in relatively sandy soils. Grassland ecological sites in the Monument also are characterized by coarse-loamy or sandy soils, thus this same soil-hydrologic principle may have contributed to the finding that these sites had relatively low frequencies of low ratings for all three attributes of rangeland health.

Management. Seeded areas associated with the two sagebrush ecological sites on fine-loamy soils had the highest frequencies of low ratings for all three attributes of rangeland health (Table 4). This suggests that past vegetation treatments associated with these two ecological sites generally have not provided long-term ecological benefits compared with untreated areas, although without further research it is difficult to know the relative degree to which degraded conditions in seedings are attributable to pretreatment land uses, long-term effects of mechanical treatments themselves, or posttreatment management. However, it is likely that interactions between soil properties and posttreatment management played a role in the development of poor rangeland-health conditions documented in Semidesert Loam and Upland Loam seedings on the Monument.

Allotment management plans in the past typically have allowed higher levels of forage utilization by livestock in seedings than in comparable untreated areas (P. Chapman, personal communication, June 2007), largely because nonnative forage grasses such as A. cristatum are more tolerant of heavy grazing than some native grasses (e.g., Richards and Caldwell 1985). This high-use management strategy inadvertently may have contributed to the relatively degraded conditions found in seedings because of the inherent sensitivity of fine-loamy soils to adverse hydrologic changes, as well as their susceptibility to compaction caused by trampling or other compressive forces (Hillel 1998). Of the ecological sites in Table 4, the seeded Upland Loam, untreated Semidesert Loam, and seeded Semidesert Loam sites had the highest frequencies of assessments with low ratings (moderate or greater departure from reference conditions) for soil compaction $(35.0 \%, 22.5 \%$, and $20.8 \%$, respectively), which is one of the four qualitative indicators that applies to all three attributes of rangeland health (Pellant et al. 2000; Pyke et al. 2002). On the Monument, the typical seasons of livestock use are winter and spring (when soils are most likely to be moist and thus most susceptible to compaction) for the Semidesert Loam site and summer and fall for the Upland Loam site. Because of elevational differences, winter mule deer use of the Semidesert Loam ecological site also tends to be greater than that of the Upland Loam ecological site. Drier soils during summer and fall use may explain why low ratings for soil compaction were less frequent $(13.3 \%)$ for untreated Upland Loam assessments than for untreated Semidesert Loam assessments.

\section{Patterns Within the Semidesert Loam Ecological Site}

Multivariate Gradients in Ecosystem Condition. Analyses of quantitative data collected during assessments of the Semidesert Loam (Wyoming big sagebrush) ecological site describe two multivariate gradients in ecosystem condition (Fig. 2a). Interspace soil aggregate stability and BSC cover tended to vary independently of total plant cover, functional-group richness and diversity, and percentage of bare ground (Fig. 2a). These results support approaches to rangeland assessment and monitoring that focus on multiple indicators of soil stability, hydrologic function, and biotic integrity rather than on plant community composition alone (Pellant et al. 2000, 2005; Herrick et al. 2005). Soil aggregate stability is related to several ecosystem processes associated with concepts of soil quality and rangeland health including erosion resistance, infiltration capacity, and soil biotic activity (Herrick et al. 1999, 2001). Likewise, BSCs are important contributors to soil stability (Belnap 1995; Williams et al. 1995a, 1995b), nutrient cycling (Evans and Lange 2003), and biological diversity (Rosentreter and Belnap 2003). Because soil-surface roughness increases residence time of runoff on hillslopes (Ward and Trimble 2004), roughness attributable to well-developed BSCs also has been cited as a factor that can enhance runoff retention and infiltration relative to comparable soils without well-developed BSCs (Belnap 2003; Warren 2003). This provides strong rationale for including BSCs (abundance, spatial continuity, and degree of roughness) as indicators of hydrologic functioning for ecological sites with high BSC potential.

Consistent with results of Bowker et al. (2006), data reported here (Fig. 3c) indicate the high BSC potential of soils associated with the Semidesert Loam ecological site. Three distinct soils (Barx series; Progresso series, cool phase; and Ruinpoint series) were found to have BSC cover greater than $40 \%$, with maximum BSC cover of $56 \%$ on the Barx series, which is the dominant soil associated with this ecological site in the Monument. Because of the hydrologic sensitivity and high BSC potential of fine-loamy soils associated with this ecological site, the functional significance of BSCs for runoff retention and erosion resistance is particularly high. The steep decline in mean BSC cover between assessment locations assigned NS ratings and those assigned SM ratings for the three attributes of rangeland health (Fig. 3c) also indicates the low resistance and resilience of well-developed BSCs to disturbance (Belnap and Eldridge 2003). In combination, these factors suggest that BSC loss and the degradation of hydrologic and soil-stabilization functions performed by BSCs on fine-loamy soils likely played a role in the development of poor rangeland-health conditions documented for this ecological site.

Relations Between Quantitative and Qualitative Data. Quantitative data exhibited a large degree of variability among Semidesert Loam locations that were assigned the same qualitative ratings by assessment teams (Figs. $2 \mathrm{~b}-2 \mathrm{~d}$ ). Some of this variability probably reflects the fact that ratings for the three qualitative attributes were based on suites of multiple 
indicators, several of which are difficult to measure and thus were not addressed by the quantitative sampling (Pellant et al. 2000; Pyke et al. 2002). Accordingly, variations in the status of indicators that were evaluated solely on a qualitative basis could have caused variations in rangeland-health ratings among assessment locations that might have been similar with respect to the quantitative variables.

It is also probable that the assessment process was not as consistent as it might have been had qualitative ratings been linked more explicitly with the quantitative data. Although quantitative data certainly were useful during the assessment process, they would have been more effective in improving assessment consistency on a real-time basis if thresholds between rating classes (NS, SM, M, ME, and E) were defined by ranges in values for one or more quantitative variables. The reference worksheet included in version 4 of the IIRH technique (Pellant et al. 2005) is a significant improvement that seeks to establish such a quantitative framework for rating indicators. This approach will work well for indicators that are easily quantified (e.g., percentage of bare ground) but will be less effective for indicators that are difficult to quantify (e.g., amount and distribution of overland flow paths; Table 2). Ideally, quantitative rating frameworks would be developed through process-based studies conducted on an ecological-site basis, but resources are insufficient to support this work for more than a small number of rangeland ecological sites. An alternative is to develop quantitative rating frameworks for specific ecological sites on the basis of existing, published research and through the use of standardized sampling techniques (e.g., Herrick et al. 2005) to acquire regional data sets describing ranges of variability across gradients of land use and condition, including sites heavily impacted by human activities as well as relatively unimpacted reference sites (Whitford 1998; Tongway and Hindley 2004). Quantitative data describing ecosystem-specific condition gradients (e.g., Figs. 2a and 3; Bosch and Kellner 1991) would be of utility to a wide range of institutions and stakeholders involved in assessment, monitoring, and sustainable management of rangeland ecosystems (e.g., Parrish et al. 2003), as well as to scientists engaged in related research activities (Herrick et al. 2006; Vavra and Brown 2006). The absence of such contextual data sets constrains the interpretation of data from moment-intime ecological assessments, whether based on qualitative or quantitative techniques.

Additional Lessons Learned From Application of the Technique As applied in this project, the IIRH technique had two important and related strengths. First, it was effective in broadening many practitioners' perspectives concerning the number and types of ecological attributes encompassed by the notion of "rangeland health." Staff who had previously focused primarily on key forage species or measures of plant community composition became attuned to soil and hydrologic processes and their importance for evaluating the status of rangeland ecosystems. Second, the technique proved valuable as a tool for facilitating discussion among diverse practitioners and stakeholders about ecological processes in rangelands.

Four factors would improve application of the IIRH technique relative to its application in this project. As discussed above, consistency would be improved by greater integration of quantitative data in the assessment technique. Second, a probabilistic sampling design (e.g., Theobald et al. 2007) would enable spatial analyses and inferences not possible with the judgment-based design used in this project. Third, the prominence of soil and hydrologic indicators in the IIRH technique calls for practitioners to have greater professional knowledge of these topics. Soil expertise is lacking in most BLM field offices (B. Ypsilantis, personal communication, July 2007), and a trained soil scientist participated in only 7 of 507 assessments in this project. As a consequence, it is probable that there was a tendency for assessment teams to understate the degree to which particular soil indicators (e.g., soil instability, soil surface degradation, and compaction) were expressed across the project area. Finally, conceptual models of ecosystem dynamics (e.g., Bestelmeyer et al. 2004) need to play a stronger, more explicit role in the assessment process to enhance the information content of assessment results and thus their value for informing the development of effective strategies for management and restoration (Briske et al. 2005; Herrick et al. 2006; Hobbs 2007).

\section{MANAGEMENT IMPLICATIONS}

The qualitative IIRH technique used in this project yielded meaningful data regarding the status of three ecosystem attributes (soil/site stability, hydrologic function, and biotic integrity) and how the status of these attributes varied among and within a large number of ecological sites across a 760000 ha landscape. Patterns among ecological sites in terms of the frequency of assessments with low ratings for all three attributes appear attributable to several interacting factors including 1) potential primary production and long-term exposure to production-dependent land-use activities such as livestock grazing; 2) the presence of unpalatable woody plants that have the capacity to increase and become persistent site dominants due to selective herbivory, absence of fire, or succession; 3) soil texture through effects on hydrologic responses to grazing, trampling, and other disturbances; and 4) past management that resulted in high livestock use of ecological sites with sensitive fine-loamy soils following treatments designed to increase forage availability. In particular, results indicate that big sagebrush ecological sites with relatively high production potential had high frequencies of assessments with low ratings for all three ecosystem attributes, whereas shallow-soil ecological sites with relatively low production potential and the presence of Utah juniper and/or Colorado pinyon had low frequencies of assessments with low ratings for all three attributes. Areas where fine-loamy big sagebrush ecological sites were seeded in the past to increase livestock forage were characterized by frequencies of low rangeland health ratings that were higher than or similar to comparable untreated areas, suggesting that these treatments have not provided long-term ecological benefits relative to untreated areas. For seeded areas, it is likely that interactions between soil properties and posttreatment management played a role in the development of poor rangeland-health conditions documented by assessments. These results-that sites with the greatest production potential tended to be the most degraded, 
and that net effects of past management treatments have not been ecologically beneficial—suggest that ongoing management, restoration treatments, and posttreatment management of these ecological sites should be tailored to account for their sensitivity to degradation.

\section{ACKNOWLEDGMENTS}

More than 50 BLM, NPS, and NRCS staff assisted with planning and implementation of this project. Major contributions were made by Laura Fertig, Walter Fertig, Dennis Pope, Doug Powell, Mary Lou Zimmerman, Bill Falvey, Allan Bate, Sean Stewart, Rick Oyler, Harry Barber, Jeff Chynoweth, Sarah Yarborough, Alan Titus, Kezia Nielsen, Chris Killingsworth, Gregg Christensen, Andrew Dubrasky, Cory Black, Dan Yarborough, and Kent Sutcliffe. Former Monument managers Kate Cannon and Dave Hunsaker were instrumental in the initiation and completion of this effort. Jayne Belnap, Brandon Bestelmeyer, Matthew Bowker, Marietta Eaton, Walter Fertig, Sam Fuhlendorf, Jeffrey Herrick, David Pyke, Roger Rosentreter, and two anonymous reviewers provided comments that improved the quality of the manuscript.

\section{LITERATURE CITED}

BAKER, W. L. 2006. Fire and restoration of sagebrush ecosystems. Wildlife Society Bulletin 34:177-185.

Belnap, J. 1995. Surface disturbances: their role in accelerating desertification. Environmental Monitoring and Assessment 37:39-57.

Belnap, J. 2003. Comparative structure of physical and biological soil crusts. In: J. Belnap and O. L. Lange [EDS.]. Biological soil crusts: structure, function, and management. 2nd ed. Berlin, Germany: Springer-Verlag. p. 177-191.

Belnap, J., AND D. J. EldRIDGe. 2003. Disturbance and recovery of biological soil crusts. In: J. Belnap and O. L. Lange [EDS.]. Biological soil crusts: structure, function, and management. 2nd ed. Berlin, Germany: Springer-Verlag. p. 363-383.

Belnap, J., J. R. Welter, N. B. Grimm, N. Barger, and J. A. Ludwig. 2005. Linkages between microbial and hydrologic processes in arid and semiarid watersheds. Ecology 86:298-307.

Bestelmeyer, B. T., J. E. Herrick, J. R. Brown, D. A. Trujillo, and K. M. Havstad. 2004. Land management in the American Southwest: a state-and-transition approach to ecosystem complexity. Environmental Management 34:38-51.

Bosch, O. J. H., And K. Kellner. 1991. The use of a degradation gradient for the ecological interpretation of condition assessment in the western grassland biome of southern Africa. Journal of Arid Environments 21:21-29.

Bowker, M. A., J. Belnap, AND M. E. Mıller. 2006. Spatial modeling of biological soil crusts to support rangeland assessment and monitoring. Rangeland Ecology and Management 59:519-529.

Bradley, M. S. 1999. A history of Kane County. Salt Lake City, UT, USA: Utah State Historical Society. 380 p.

Briske, D. D., S. D. Fuhlendorf, and F. E. Smeins. 2005. State-and-transition models, thresholds, and rangeland health: a synthesis of ecological concepts and perspectives. Rangeland Ecology and Management 58:1-10.

Cingolani, A. M., I. Noy-Meir, and S. Díaz. 2005. Grazing effects on rangeland diversity: a synthesis of contemporary models. Ecological Applications 15:757-773.

Connelly, J. W., S. T. Knick, M. A. Schroeder, and S. J. Stiver. 2004. Conservation assessment of greater sage-grouse and sagebrush habitats. Cheyenne, WY: Western Association of Fish and Wildlife Agencies. Available at: http://sagemap. wr.usgs.gov/Docs/Greater_Sage-grouse_Conservation_Assessment_060404.pdf. Accessed 25 March 2008.

Coulloudon, B., K. Eshelman, J. Gianola, N. Habich, L. Hughes, C. Johnson, M. Pellant, P. Podborny, A. Rasmussen, B. Robles, P. Shaver, J. Spehar, and J. W. Willoughby. 1999. Sampling vegetation attributes. Denver, CO, USA: US Department of the
Interior, Bureau of Land Management, National Science and Technology Center, Interagency Technical Reference 1734-4. 163 p.

Daly, C., R. P. Neilson, and D. L. Phillips. 1994. A statistical-topographic model for mapping climatological precipitation over mountainous terrain. Journal of Applied Meteorology 33:140-158.

de Soyza, A. G., J. W. Van Zee, W. G. Whitford, A. Neale, N. Tallent-Hallsel, J. E. HerRick, and K. M. Havstad. 2000a. Indicators of Great Basin rangeland health. Journal of Arid Environments 45:289-304.

de Soyza, A. G., W. G. Whitford, and A. R. Johnson. 2000b. Assessing and monitoring the health of western rangeland watersheds. Environmental Monitoring and Assessment 64:153-166.

Díaz, S., D. D. Briske, and S. Mclntyre. 2002. Range management and plant functional types. In: A. C. Grice and K. C. Hodgkinson [EDS.]. Global rangelands: progress and prospects. Wallingford, UK: CABI Publishing. $\mathrm{p}$. 81-100.

Doelling, H. H., R. E. Blackett, A. H. Hamblin, J. D. Powell, and G. L. Pollock. 2000. Geology of Grand Staircase-Escalante National Monument, Utah. In: D. A. Sprinkel, T. C. Chidsey, Jr., and P. B. Anderson [EDs.]. Geology of Utah's parks and monuments. Salt Lake City, UT, USA: Utah Geological Association. p. 189-231.

Eckert, R. E., JR., F. F. Peterson, M. S. Meurisse, and J. L. Stephens. 1986. Effects of soil-surface morphology on emergence and survival of seedlings in big sagebrush communities. Journal of Range Management 39:414-420.

Evans, R. D., and O. L. Lange. 2003. Biological soil crusts and ecosystem nitrogen and carbon dynamics. In: J. Belnap and 0. L. Lange [EDS.]. Biological soil crusts: structure, function, and management. 2nd ed. Berlin, Germany: Springer-Verlag. p. 263-279.

Floyd, M. L., T. L. Fleischner, D. D. Hanna, and P. Whitefield. 2003. Effects of historic livestock grazing on vegetation at Chaco Culture National Historic Park, New Mexico. Conservation Biology 17:1703-1711.

Harris, T. A., G. P. Asner, And M. E. Miller. 2003. Changes in vegetation structure after long-term grazing in pinyon-juniper ecosystems: integrating imaging spectroscopy and field studies. Ecosystems 6:368-383.

Herrick, J. E., B. T. Bestelmeyer, S. Archer, A. J. Tugel, and J. R. Brown. 2006. An integrated framework for science-based arid land management. Journal of Arid Environments 65:319-335.

Herrick, J. E., J. W. Van Zee, K. M. Havstad, L. M. Burkett, and W. G. Whitford. 2005. Monitoring manual for grassland, shrubland and savanna ecosystems. Volume I: quick start. Las Cruces, NM, USA: USDA-ARS Jornada Experimental Range. $36 \mathrm{p}$.

Herrick, J. E., M. A. Weltz, J. D. Reeder, G. E. Schuman, and J. R. Simanton. 1999. Rangeland soil erosion and soil quality: role of soil resistance, resilience, and disturbance regime. In: R. Lal [ED.]. Soil erosion and soil quality. Boca Raton, FL, USA: CRC Press. p. 209-233.

Herrick, J. E., W. G. Whitford, and M. Walton. 2001. Field soil aggregate stability kit for soil quality and rangeland health evaluations. Catena 44:27-35.

HilleL, D. 1998. Environmental soil physics. San Diego, CA, USA: Academic Press. $771 \mathrm{p}$.

HoBBS, R. J. 2007. Setting effective and realistic restoration goals: key directions for research. Restoration Ecology 15:354-357.

Hunt, C. B. 1974. Natural regions of the United States and Canada. San Francisco, CA, USA: W. H. Freeman. 725 p.

Huston, M. 1979. A general hypothesis of species diversity. The American Naturalist 113:81-101.

Knick, S. T., D. S. Dobkin, J. T. Rotenberry, M. A. Schroeder, W. M. Vander Haegen, AND C. VAN RIPER III. 2003. Teetering on the edge or too late: conservation and research issues for avifauna of sagebrush habitats. The Condor 105: 611-634.

Ludwig, J. A., G. N. Bastin, V. H. Chewings, R. W. Eager, and A. C. Liedloff. 2007. Leakiness: a new index for monitoring the health of arid and semiarid landscapes using remotely sensed vegetation cover and elevation data. Ecological Indicators 7:442-454.

Ludwig, J. A., R. W. Eager, G. N. Bastin, V. H. Chewings, and A. C. Liedloff. 2002. A leakiness index for assessing landscape function using remote sensing. Landscape Ecology 17:157-171. 
Lunt, I. D., D. J. Eldridge, J. W. Morgan, and G. B. Witt. 2007. Turner Review No. 13. A framework to predict the effects of livestock grazing and grazing exclusion on conservation values in natural ecosystems in Australia. Australian Journal of Botany 55:401-415.

McCune, B. P., and J. B. Grace. 2002. Analysis of ecological communities. Gleneden Beach, OR, USA: MJM Software Design. $300 \mathrm{p}$.

Milchunas, D. G., O. E. Sala, and W. K. Lauenroth. 1988. A generalized model of the effects of grazing by large herbivores on grassland community structure. The American Naturalist 132:87-106.

Miller, R. F., T. J. Svejcar, And N. E. West. 1994. Implications of livestock grazing in the Intermountain sagebrush region: plant composition. In: M. Vavra, W. A. Laycock, and R. D. Pieper [EDS.]. Ecological implications of livestock herbivory in the West. Denver, CO, USA: Society for Range Management. p. 101-146.

[NRC] National Research Council. 1994. Rangeland health: new methods to classify, inventory, and monitor rangelands. Washington, DC, USA: National Academy Press. $180 \mathrm{p}$.

[NRCS] USDA Natural Resources Conservation Service. 2003. National range and pasture handbook. Revision 1. Washington, DC, USA: US Department of Agriculture, Natural Resources Conservation Service. 575 p.

[NRCS] USDA Natural Resources Conservvation Service. 2005. Soil survey of Grand Staircase-Escalante National Monument area, parts of Kane and Garfield counties, Utah. Salt Lake City, UT, USA: US Department of Agriculture, Natural Resources Conservation Service. 577 p.

Parrish, J. D., D. P. Braun, and R. S. Unnasch. 2003. Are we conserving what we say we are? Measuring ecological integrity within protected areas. BioScience 53:851-860.

Pellant, M., P. L. Shaver, D. A. Pyke, and J. E. Herrick. 2000. Interpreting indicators of rangeland health. Version 3. Denver, CO, USA: US Department of the Interior, Bureau of Land Management, Interagency Technical Reference TR1734-6. $118 \mathrm{p}$.

Pellant, M., P. L. Shaver, D. A. Pyke, and J. E. Herrick. 2005. Interpreting indicators of rangeland health. Version 4. Denver, CO, USA: US Department of the Interior, Bureau of Land Management, Interagency technical reference TR1734-6. 122 p.

Pierson, F. B., W. H. Blackburn, S. S. Van Vactor, and J. C. Wood. 1994. Partitioning small scale spatial variability of runoff and erosion on sagebrush rangeland. Water Resources Bulletin 30:1081-1089.

PYKE, D. A., AND J. E. HeRRICK. 2003. Transitions in rangeland evaluations: a review of the major transitions in rangeland evaluations during the last 25 years and speculation about future evaluations. Rangelands 25:22-30.

Pyke, D. A., J. E. Herrick, P. L. Shaver, and M. Pellant. 2002. Rangeland health attributes and indicators for qualitative assessment. Journal of Range Management 55:584-597.

Rasmussen, L. L., and J. D. Brotherson. 1986. Response of winterfat (Ceratoides lanata) communities to release from grazing pressure. Great Basin Naturalist 46:148-156.

Richards, J. H., and M. M. Caldwell. 1985. Soluble carbohydrates, concurrent photosynthesis and efficiency in regrowth following defoliation: a field study with Agropyron species. Journal of Applied Ecology 22:970-920.

Rosentreter, R., and J. Belnap. 2003. Biological soil crusts of North America. In: J. Belnap and O. L. Lange [EDS.]. Biological soil crusts: structure, function, and management. 2nd ed. Berlin, Germany: Springer-Verlag. p. 31-50.

Rosentreter, R., and D. J. Eldridge. 2002. Monitoring biodiversity and ecosystem function: grasslands, deserts, and steppe. In: P. L. Nimis, C. Scheidegger, and P. A. Wolseley [EDS.]. Monitoring with lichens-monitoring lichens. Dordrecht, Netherlands: Kluwer. p. 223-237.

Spaeth, K. E., T. L. Thurow, T. H. Blackburn, and F. B. Pierson. 1996. Ecological dynamics and management effects on rangeland hydrologic processes. In:
K. E. Spaeth, F. B. Pierson, M. A. Weltz, and R. G. Hendricks [eds.]. Grazingland hydrology issues: perspectives for the 21st century. Denver, C0, USA: Society for Range Management. p. 25-51.

[SRM Task Group] Society for Range Management Task Group on Unity in Concepts and Terminology Committee. 1995. New concepts for assessment of rangeland condition. Journal of Range Management 48:271-282.

StaTSoft [computer program]. 2004. STATISTICA. Version 6. Available at: http:// www.statsoft.com. Accessed 7 March 2008.

Theobald, D. M., D. Stevens, D. White, N. S. Urquhart, A. Olsen, and J. Norman. 2007. Using GIS to generate spatially balanced random survey designs for natural resource applications. Environmental Management 40:134-146.

Thurow, T. L. 1991. Hydrology and erosion. In: R. K. Heitschmidt and J. W. Stuth [EDS.]. Grazing management: an ecological perspective. Portland, OR, USA: Timber Press. p. 141-159.

Tongway, D. J., AND N. L. Hindley. 2004. Landscape function analysis: procedures for monitoring and assessing landscapes. Canberra, Australia: CSIRO Sustainable Ecosystems. $82 \mathrm{p}$.

USDA Forest SeRVICE. 1937. Range plant handbook. Washington, DC, USA: US Department of Agriculture, Forest Service. $844 \mathrm{p}$.

Van AUKen, 0. W. 2000. Shrub invasions of North American semiarid grasslands. Annual Review of Ecology and Systematics 31:197-215.

VaVRA, M., AND J. BRown. 2006. Rangeland research: strategies for providing sustainability and stewardship to the rangelands of the world. Rangelands 28:7-14.

WALKER, B. H. 2002. Ecological resilience in grazed rangelands. In: L. H. Gunderson and L. Pritchard, Jr. [EDS.]. Resilience and the behavior of large-scale systems. Washington, DC, USA: Island Press. p. 183-193.

Ward, A. D., and S. W. Trimble. 2004. Environmental hydrology. 2nd ed. Boca Raton, FL, USA: Lewis Publishers. $475 \mathrm{p}$.

WarRen, S. D. 2003. Synopsis: influence of biological soil crusts on arid land hydrology and soil stability. In: J. Belnap and O. L. Lange [EDS.]. Biological soil crusts: structure, function, and management. 2nd ed. Berlin, Germany: Springer-Verlag. p. 349-360.

WeLCH, B. L. 2005. Big sagebrush: a sea fragmented into lakes, ponds, and puddles. Fort Collins, CO, USA: US Department of Agriculture, Forest Service, Rocky Mountain Research Station, General Technical Report RMRS-GTR-144. $210 \mathrm{p}$.

Welsh, S. D., N. D. Atwood, S. Goodrich, and L. C. Higgins [eds.]. 2003. A Utah flora. 3rd ed., revised. Provo, UT, USA: Brigham Young University. 912 p.

WEST, N. E., AND T. P. YoRKS. 2006. Long-term interactions of climate, productivity, species richness, and growth form in relictual sagebrush steppe plant communities. Western North American Naturalist 66:502-526.

Western Regional Climate Center. 2007. Western Regional Climate Center. Available at: http://www.wrcc.dri.edu. Accessed 27 March 2007.

Whitford, W. G. 1998. Validation of indicators. In: D. J. Rapport, R. Costanza, P. R. Epstein, C. Gaudet, and R. Levins [EDs.]. Ecosystem health. Malden, MA, USA: Blackwell Science. p. 205-209.

Whitford, W. G., A. G. de Soyza, J. W. Van Zee, J. E. Herrick, and K. M. Havstad. 1998. Vegetation, soil and animal indicators of rangeland health. Environmental Monitoring and Assessment 51:179-200.

Williams, J. D., J. P. Dobrowolski, D. A. Gillette, and N. E. West. 1995a. Microphytic crust influence on wind erosion. Transactions of the American Society of Agricultural Engineers 38:131-137.

Williams, J. D., J. P. Dobrowolski, and N. E. West. 1995b. Microphytic crust influence on interrill erosion and infiltration capacity. Transactions of the American Society of Agricultural Engineers 38:139-146.

ZAR, J. H. 1999. Biostatistical analysis. 4th ed. Upper Saddle River, NJ, USA: Prentice Hall. 663 p. 